\title{
Evidence for early warming and cooling in North Atlantic surface waters during the last interglacial
}

\author{
Henning A. Bauch ${ }^{1}$ and Evguenia S. Kandiano ${ }^{2}$ \\ Received 1 December 2005; revised 9 August 2006; accepted 12 September 2006; published 4 January 2007.
}

[1] In-depth analysis of planktic foraminiferal census data paired with $\delta^{18} \mathrm{O}$ records of specific indicator species provides new insight into the surface ocean evolution of the northeast Atlantic during the previous interglacial warm period (oxygen isotope stage (OIS) 5e). Full interglacial conditions existed at the study site for a maximum of only $8 \mathrm{kyr}$, between 125 and $117 \mathrm{ka}$. Highest sea surface temperatures (SSTs) occurred during early OIS 5e concomitant with high summer insolation but after the main phase of ice sheet melting of the preceding glaciation (Saalian). This early peak SST interval is marked by the appearance of tropical-subtropical species and lasted for $4 \mathrm{kyr}$ until $121 \mathrm{ka}$, as corroborated by a major change in planktic $\delta^{18} \mathrm{O}$. Relative stability in global ice volume continued for another 3-4 kyr before SSTs dropped further toward the next stadial. During early OIS 5e the situation of the surface water vertical structure appears to have been different from the early Holocene. For OIS 5e it is therefore suggested that the particular melting history of late Saalian ice had a long-lasting and profound effect on both postdeglacial surface water mass configuration in the North Atlantic and heat-moisture transfer into Europe.

Citation: Bauch, H. A., and E. S. Kandiano (2007), Evidence for early warming and cooling in North Atlantic surface waters during the last interglacial, Paleoceanography, 22, PA1201, doi:10.1029/2005PA001252.

\section{Introduction}

[2] Investigating the duration and character of the last interglacial climate, oxygen isotope stage (OIS) 5e, is an important aspect in Quaternary research because it may help to better understand our present warm phase and its future perspective. Despite great interest in this subject over many years, a number of issues concerning the climate circumstances of OIS $5 \mathrm{e}$ are by no means resolved. Some marine and terrestrial records have been interpreted as revealing one or even several major cold events during the peak of OIS 5e [Cheddadi et al., 1998; Fronval et al., 1995; Maslin et al., 1996], presumably caused by thermohaline circulation (THC) changes. However, an alternate hypothesis proposes a rather prolonged phase with warm climate conditions [Kukla et al., 1997; McManus et al., 2002] characterized by a relatively stable THC in the N. Atlantic [McManus et al., 1994; Oppo et al., 1997]. Furthermore, still other marine records reveal some notable deep and surface ocean variability which occurred during the cooling transition from the warm interglacial OIS 5e into the next cold phase, stadial OIS 5d [Chapman and Shackleton, 1999; Adkins et al., 1997; Lehman et al., 2002].

[3] Because of their good correlation with distinct water masses and sea surface temperatures (SSTs), planktic foraminifers have become a traditional tool in paleoceanography (Figure 1) [Bandy, 1959; Imbrie and Kipp, 1971; CLIMAP, 1976]. Past SSTs reconstructed from down-core planktic fora-

\footnotetext{
${ }^{1}$ Mainz Academy of Sciences, Humanities, and Literature, IFM-GEOMAR, Kiel, Germany.

${ }^{2}$ IFM-GEOMAR, Kiel, Germany.

Copyright 2007 by the American Geophysical Union. 0883-8305/07/2005PA001252
}

miniferal census counts of the midlatitude NE Atlantic clearly indicate SSTs during OIS 5e about $2^{\circ} \mathrm{C}$ warmer than during the present interglacial OIS 1 [Ruddiman et al., 1986; Kandiano et al., 2004]. While this finding is in general accordance with European pollen data from similar latitudes [e.g., Guiot et al., 1993], for the marine realm it has been proven difficult to identify intra-interglacial fluctuations using foraminiferal-based SSTs [Oppo et al., 1997]. On the one hand, this may be due to the fact that this proxy has a limited potential to resolve smaller-scale, intra-interglacial SST variability [Waelbroeck et al., 1998]. On the other hand, the modern and late Pleistocene foraminiferal assemblage in the subpolar North Atlantic region is made up of a handful of rather dominant species [Kipp, 1976; Kandiano and Bauch, 2003]. One of them, the polar species Neogloboquadrina pachyderma sinistral (s), has been successfully applied as relative indicator for climate-related surface ocean changes on glacial and glacial-interglacial scales (Figure 1) [Bond et al., 1992; McManus et al., 1994]. Probably owing to their relatively wide temperature adaptations and geographic distributions in the North Atlantic the interglacially more dominant subpolar species were considered less important on species level to evaluate interglacial climate changes during warmer interglacials.

[4] To open up new perspectives for paleoceanographic interpretations of warm interglacials in the subpolar North Atlantic, we introduce here a modified approach of foraminiferal analysis which combines conventional species analysis and SST estimates with faunal data of species having a tropical-subtropical origin. This alternative method is applied to a sediment core from a key oceanographic intersection in the northeast Atlantic (where the interaction between different water masses critically influences the intensity of the northward propagating THC; Figure 1). To better understand the 

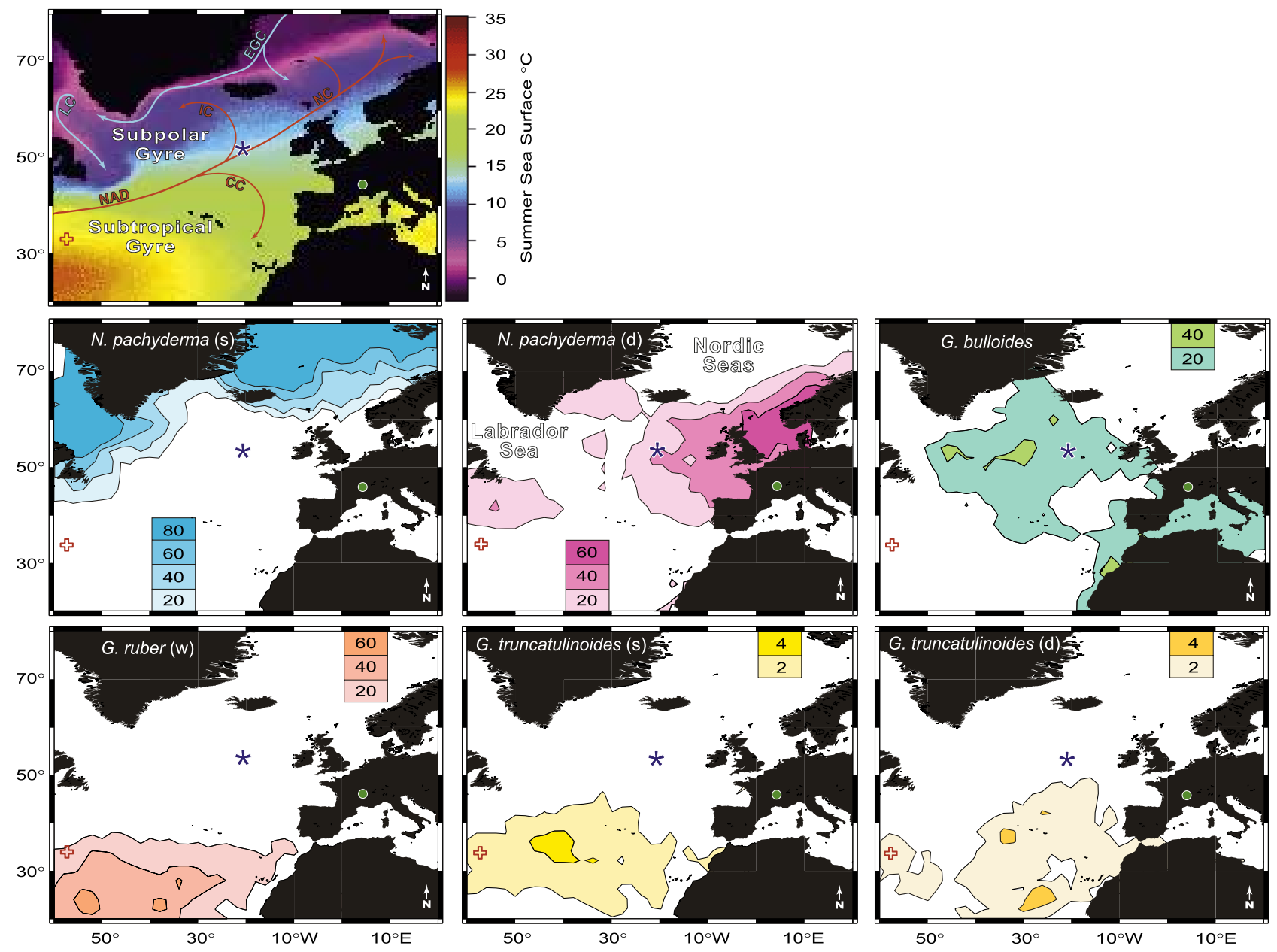

Figure 1. (top) North Atlantic sea surface temperatures (average for mid-June 1985-1997; see http:// podaac-www.jpl.nasa.gov/sst/images/clim.gif), major gyre systems, and warm/cold (red/blue) surface currents in comparison with the (middle) modern biogeography (surface sediments) of the dominant, polarsubpolar-transitional and (bottom) rare, tropical-subtropical indicator species of planktic foraminifers. The studied core M23414 is marked by a blue asterisk. Also shown are the discussed reference sites MD95-2036 (red cross) and Ribains Maar (green circle). Abbreviations are EGC, East Greenland Current; LC, Labrador Current; NC, Norwegian Current; IC, Irminger Current; CC, Canary Current; and NAD, North Atlantic Drift.

paleoenvironmental meaning of the results from OIS 5e, the various foraminiferal data are combined with other conventional proxy records and evaluated against the same type of data which were also obtained for the present warm period (OIS 1). The identification of a series of prominent events across OIS 5e allows us to describe and interpret in more detail the major water mass changes in the North Atlantic. The timing of these events is then used to make further assumptions on how these ocean changes were connected to the overall climate development of the last interglacial.

\section{Material and Methods}

[5] The position of core M23414 (53 ${ }^{\circ} 32 \mathrm{~N} / 20^{\circ} 17 \mathrm{~W} ; 2196 \mathrm{~m}$ water depth) is situated along the axis of the North Atlantic Drift (NAD), just between the subpolar and subtropical gyres (Figure 1). The specific dynamic of these two gyres has been recently described as an important parameter which controls the water mass transfer of the NAD toward polar latitudes [Hatun et al., 2005].

[6] This core has a well-established stratigraphy back to OIS 13, based on SPECMAP [Martinson et al., 1987] and radiocarbon chronologies [Helmke and Bauch, 2001; Didié and Bauch, 2002; Helmke et al., 2002]. Moreover, records of planktic and benthic foraminiferal $\delta^{18} \mathrm{O}$ isotopes, icebergrafted debris (IRD) and sediments reflectance reveal millennialscale changes in surface water mass properties that are typical for this region [e.g., Chapman and Shackleton, 1999]. To improve on all data published from this core site, the sections of OIS 1 and 5e have been resampled and reanalyzed in continuous $1 \mathrm{~cm}$ steps. Samples were cut from the core as large, thin slices $(\sim 30 \mathrm{sqcm})$ to reduce some bias that might be expected from bioturbational mixing. The sampling of the two core sections corresponds to an average time resolution of 315 years (median 380 years) for the Holocene and 321 years (median 270 years) for OIS 5e. 


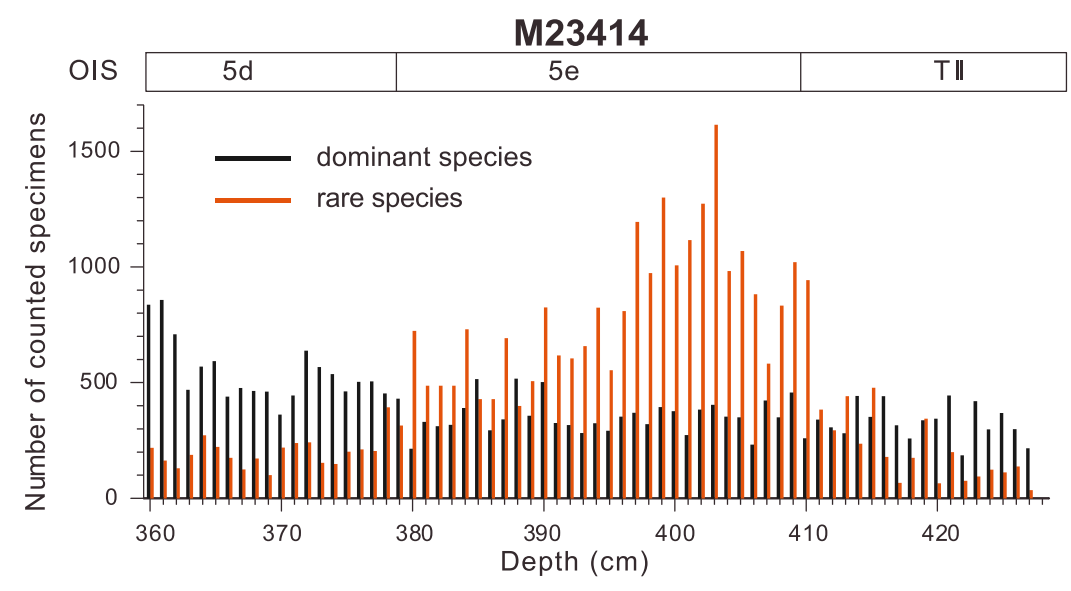

Figure 2. OIS 5e section of core M23414 exemplifying the number of actually counted specimens per sample for each of the two foraminiferal groups.

[7] IRD countings were newly performed on the $>150 \mu \mathrm{m}$ size fraction. Stable oxygen isotope ratios were analyzed at the Leibniz Laboratory (Kiel University) on the two planktic foraminifers $N$. pachyderma dextral ( 28 specimens; average size $\sim 250 \mu \mathrm{m})$ and Globigerina bulloides ( $\sim 15$ specimens; average size $\sim 350 \mu \mathrm{m}$ ), as well as on the benthic foraminifer Cibicidoides wuellerstorfi ( $7-10$ specimens; average size $\sim 450 \mu \mathrm{m}$ ).

\subsection{Foraminiferal Counting Technique}

[8] The planktic foraminiferal assemblage in the eastern North Atlantic is dominated by few species [Kandiano et al., 2004]: a polar species (total relative abundance up to $100 \%$ during cold times) and 6 temperate-subpolar species (total relative abundance up to $89 \%$ during interglacials). The remainder is constituted by 10 subtropical to tropical representatives, hereinafter named "rare species," whose relative abundances usually do not exceed $2 \%$ during peak warm interglacial time. Dominant species were counted in the $>150 \mu \mathrm{m}$ fraction following the conventional procedure, i.e., reducing the size of a sample by means of a microsplitter and counting no less than 300 specimens. To achieve a high statistical robustness, counts on the rare species were performed in a second run, and separately from the conventional method described above. For this procedure, the entire unsplit sample fraction $>150 \mu \mathrm{m}$ was considered, but only rare species were counted. In most cases, more than 300 specimens of rare species per sample could be counted (Figure 2). The results of the two counting methods were then added and calculated into census data.

\subsection{Foraminiferal Depth Habitats}

[9] The rare species records analyzed in this study reflect those foraminiferal species which are important indicators of the modern environments of low-to-middle latitudes in the North Atlantic (Figure 1), and whose ecological preferences are relatively well known [Hemleben et al., 1989]. Globigerinoides ruber white $(\mathrm{w})$ is a shallow dweller in tropical-subtropical surface waters showing a high correlation with SSTs in its geographical distribution; Globorotalia truncatulinoides is the deepest dweller among modern species [Lohmann and Schweitzer, 1990] and an occurrence of this species potentially records changes in the intensity of warm water advec- tion to a greater water depth. Right-coiled and left-coiled varieties of G. truncatulinoides were considered separately, as they have a different geographical distribution in the North Atlantic (Figure 1) [Thiede, 1971; Herman, 1972].

[10] In the present northeast Atlantic, G. bulloides and $N$. pachyderma dextral (d) occupy the upper $60 \mathrm{~m}$ of the water column. However, their seasonal peak abundance seems to differ: while G. bulloides is most common during springtime, $N$. pachyderma (d) is more abundant in late summer [Schiebel et al., 2001; Schiebel and Hemleben, 2000]. Although it is impossible to resolve our records on a seasonal basis, as it is the case with most deep-sea sediment cores, it must be expected that any significant past ocean change may also cause a shift in seasonal preference of either of these two species, or any of the others for this matter. Such a climate-driven change in behavior would not only lead to a significant change in abundance but could also account for possible differences in the isotopic signature [Ganssen and Kroon, 2000].

\subsection{SST Calculations}

[11] The present summer SST range across the North Atlantic region (Figure 1) is well reflected in the modern geographical distribution of dominant and rare foraminiferal indicator species as found in the foraminiferal database "ATL916" (http://www.pangaea.de/Projects/GLAMAP2000/). Using this database in combination with oceanographic atlas data [Antonov et al., 1998], down-core SSTs were calculated. For comparison, three alternative approaches were employed: transfer function technique (TFT) [Imbrie and Kipp, 1971], modern analogue technique (MAT) [Prell, 1985], and revised analogue method (RAM) [Waelbroeck et al., 1998].

\section{Results}

\subsection{Down-Core Stratigraphy}

[12] On the basis of low oxygen isotope values OIS 1 and 5e are clearly recognizable in the upper $430 \mathrm{~cm}$ of core M23414 as times of minimal global ice (Figure 3 ). This is characterized by a first steeply decreasing, and then minimized deposition of IRD, indicating that any influence of iceberg melt on THC strength was also strongly reduced. The entire period of OIS 5 is known to show, besides its major sub- 


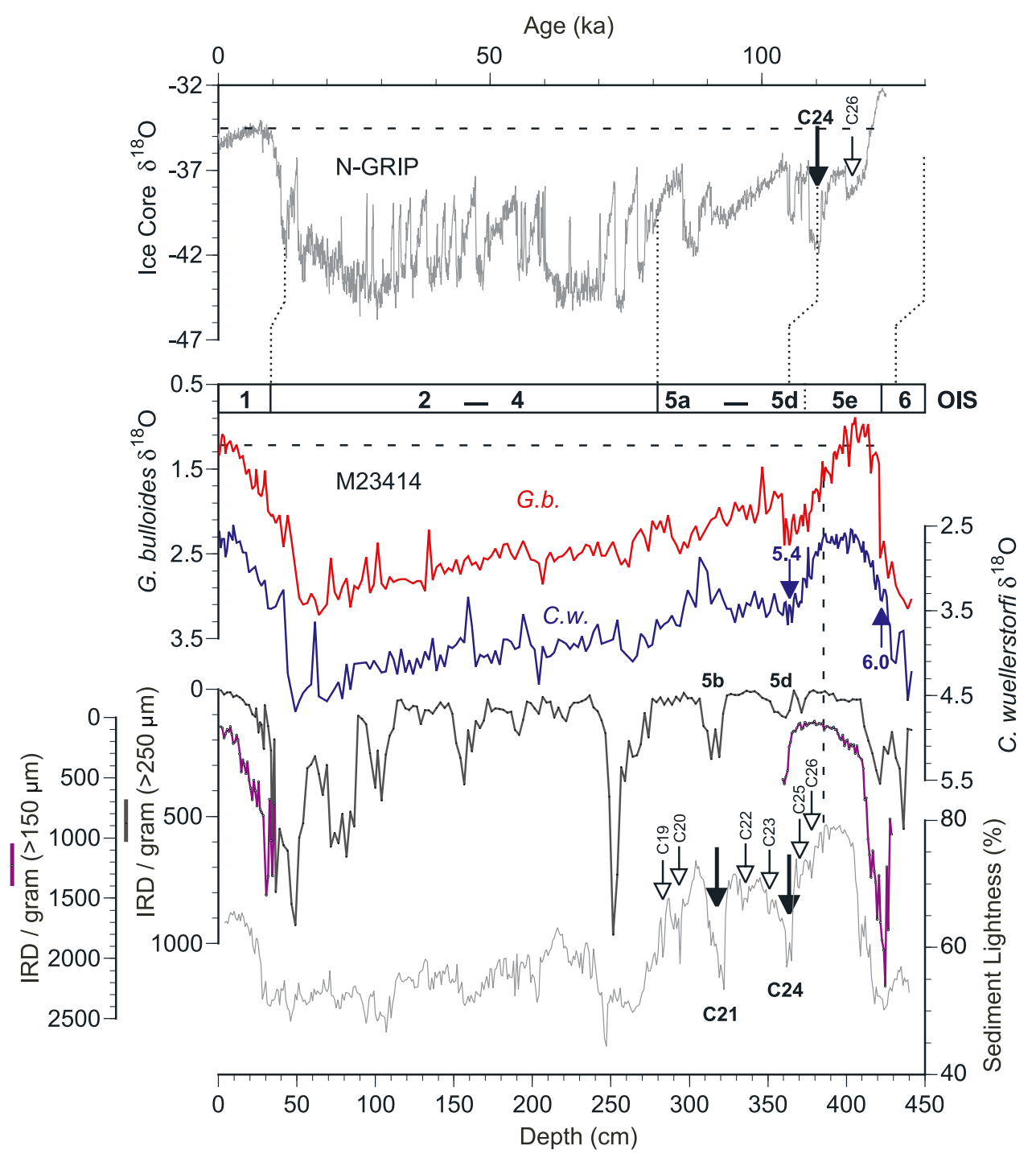

Figure 3. Comparison of Greenland ice core data [North Greenland Ice Core Project Members, 2004] with proxy records from kastencore M23414. Stratigraphic subdivision of M23414 shows oxygen isotope stage (OIS) boundaries and substages as well as the two SPECMAP date events used to construct the time frame for OIS 5e via interpolation [Martinson et al., 1987]. Records of planktic (Globigerina bulloides (G.b.)) and benthic (Cibicidoides wuellerstorfi (C.w.)) foraminiferal isotopes are shown alongside with iceberg-rafted debris (IRD) and sediment reflectance (in greyscale, 0-100). Black and white arrows denote major and minor climate cooling events during OIS 5 as described from other marine sediment records [cf. Chapman and Shackleton, 1999]. The lowermost event C26 is not associated with IRD, whereas $\mathrm{C} 25$ is, especially in the larger size fraction samples.

stages, a series of millennial-scale cold events [McManus et al., 1994; Chapman and Shackleton, 1999]. As in other records from the northeast Atlantic, these climate variations are also reflected in the sediment lightness and IRD records of core M23414. The earliest of such events after the peak of OIS 5 e is notably not associated with IRD and occurred during the climate transitions toward the cold interstadial OIS5d. This event has been argued to result from contemporaneous surface ocean cooling [Chapman and Shackleton, 1999; Lehman et al., 2002]. However, contrary to other studies from the subtropical northwest Atlantic [e.g., Adkins et al., 1997] core M23414 also reveals that planktic $\delta^{18} \mathrm{O}$ values in G. bulloides increased notably before there was a change in benthic $\delta^{18} \mathrm{O}$ (Figure 3). Such an earlier isotopic change of about $0.5 \%$ in planktics is recognizable in other records as well [Chapman and Shackleton, 1999], and therefore seems indicative of a different climatic response between surface and deep waters during the course of OIS $5 \mathrm{e}$.

\subsection{Interglacial Comparison}

[13] Direct comparison of the present and last interglacial records reveals similar basic climate constraints but also a number of different features (Figure 4). Benthic $\delta^{18} \mathrm{O}$, together with IRD and abundances of the polar species $N$. pachyderma 


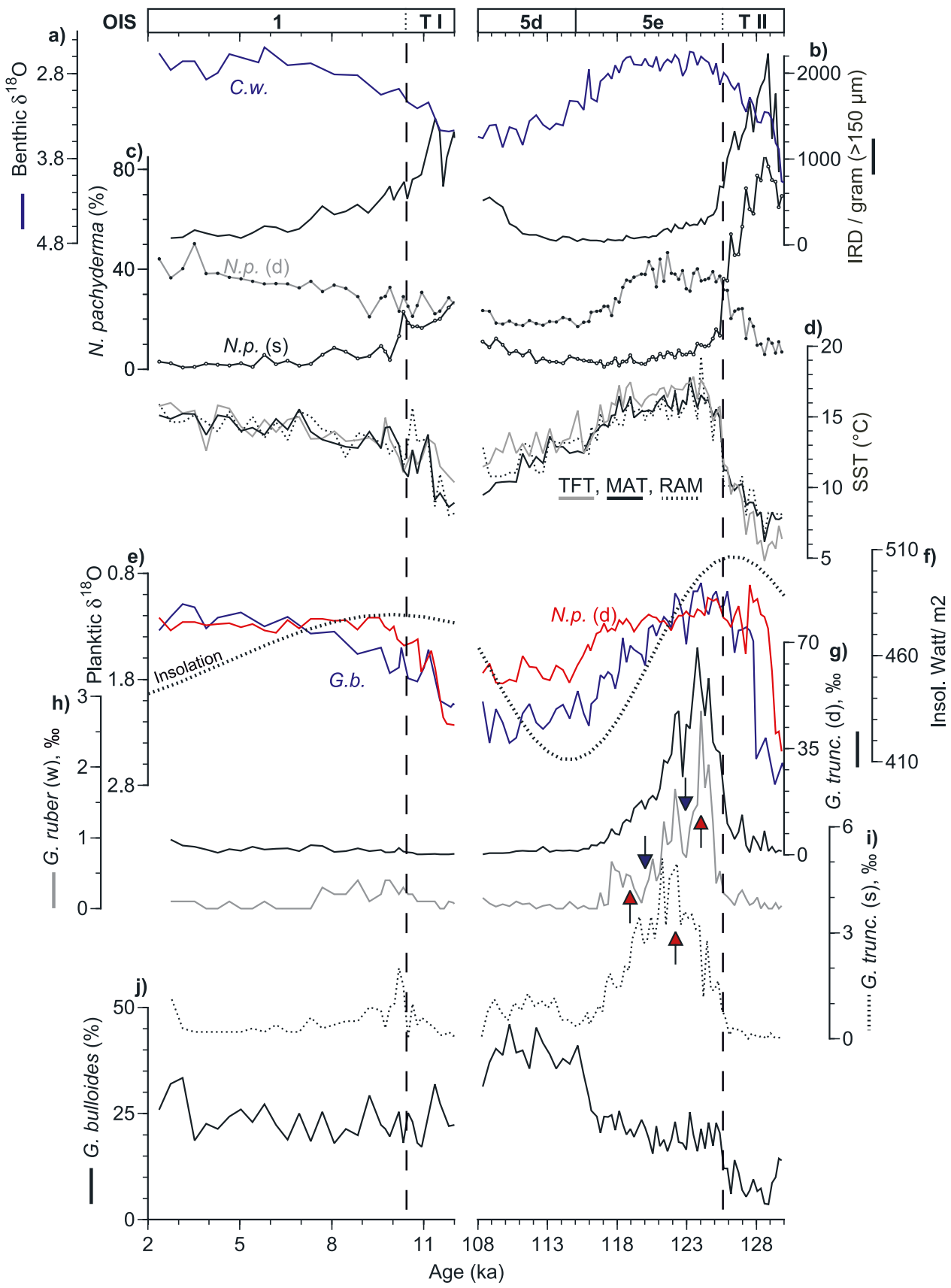

Figure 4. Comparison of climate-related proxy records in core M23414 for the OIS 5e interval and the last 12 kyr. (a) Oxygen isotopes of the benthic foraminifer Cibicidoides wuellerstorfi. (b) Number of icebergrafted detrital grains per gram of dry bulk sediment. (c) Relative abundance of the most dominant glacial and interglacial planktic foraminiferal species, polar Neogloboquadrina pachyderma (s) and subpolar $N$. pachyderma (d). (d) SST results calculated on the basis of fossil foraminiferal assemblages using three different techniques (transfer function technique (TFT), modern analogue technique (MAT), and revised analogue method (RAM)). (e) Oxygen isotope data of the two planktic foraminifers Globigerina bulloides and N. pachyderma (d). (f) Mid-June summer insolation at $65^{\circ} \mathrm{N}$ [Berger, 1978]. (g-i) Relative abundance of rare, tropical-subtropical foraminiferal species Globigerinoides ruber white (w) and Globorotalia truncatulinoides sinistral (s) and dextral (d). (j) Relative abundance of the second most dominant interglacial planktic foraminifer, subpolar-transitional G. bulloides. Dashed vertical lines denote the end of deglaciations (termination (T) I and T II) as interpreted from values of IRD and N. pachyderma (s). Arrows in OIS 5e mark some of the more prominent surface ocean changes as recorded by the rare species. Note that rare species abundances are expressed in per mille of the total assemblage. 
(s), demonstrate that cold surface conditions gradually ceased from site M23414 during the course of global deglaciations, i.e., during terminations T1 and T2. Depending on the method used, our foraminiferal SST calculations indicate about $2^{\circ} \mathrm{C}$ warmer conditions for OIS 5e in comparison to the Holocene. In OIS 5e, warmest conditions were reached directly after T2, with a second, slightly lower peak occurring around $119 \mathrm{ka}$. SSTs generally decreased thereafter, in good temporal agreement with the change in bottom water $\delta^{18} \mathrm{O}$, and never regained their previous high values.

[14] The increased occurrence of the polar surface water proxy $N$. pachyderma (s) together with IRD around $110 \mathrm{ka}$ indicates that cooler, and fresher surface waters influenced our site at this time. By contrast, the main increase in global ice volume/deepwater cooling (i.e., benthic $\delta^{18} \mathrm{O}$ ) began nearly 9 kyr earlier, after $119 \mathrm{ka}$. This distinct time lag between these two surface and deep water proxies has been argued by others to suggest a much longer benign climate phase during OIS 5e [Kukla et al., 1997; McManus et al., 2002], versus that given by the SPECMAP chronology [Martinson et al., 1987]. However, prior to this late change in the polar surface proxies, we notice an earlier change around $119 \mathrm{ka}$ in subpolar $N$. pachyderma (d). Because this early decrease of the most abundant interglacial species agrees well in time with changes in benthic $\delta^{18} \mathrm{O}$ and SSTs, these data exemplify the deficiency of the extensively used cold water proxy $N$. pachyderma (s) percentage [e.g., see Müller and Kukla, 2004] to properly resolve warm interglacial surface ocean conditions in the subpolar North Atlantic.

[15] On average, planktic $\delta^{18} \mathrm{O}$ records of $N$. pachyderma (d) and $G$. bulloides reveal slightly lighter values during OIS 5e than in the Holocene (Figures 3 and 4), apparently in general agreement with our reconstructed SST difference. Direct comparison of these two isotopic records shows a clear offset, most distinctive during the terminal phase of the two preceding glaciations. However, this species-specific isotopic offset vanishes after deglaciation, relatively more quickly in OIS 5e than in OIS 1 . In the Holocene, the same $\delta^{18} \mathrm{O}$ level was reached by both species around $7 \mathrm{ka}$, coincident with relatively stable and maximal SSTs, and coeval with the onset of deepwater production in the Nordic and Labrador seas [Hillaire-Marcel et al., 2001; Bauch et al., 2001]. In OIS 5e and after $124 \mathrm{ka}$, G. bulloides shows some lighter $\delta^{18} \mathrm{O}$ values than $N$. pachyderma (d). This pattern reverses after about $121 \mathrm{ka}$ after which $G$. bulloides retains consistently isotopically heavier $\delta^{18} \mathrm{O}$ values than $N$. pachyderma (d). Such an isotopic reversal between these two species is not seen in our youngest Holocene samples. Because of differences in depth habitat and seasonal preference of the two species, as described previously, it seems plausible that their diverging isotopic signal after $121 \mathrm{ka}$ reflects certain climate-related changes in upper ocean properties. These changes either led to a shift in seasonal behavior of the foraminifers or caused an increase in the seasonal temperature gradient of the water.

[16] The conventional faunal data in combination with our approach using rare species analyses further underscore the aforementioned differences between OIS 5e and OIS 1. While during OIS 1 the abundance of our selected tropicalsubtropical indicator species remained insignificant, they all started to appear in increased numbers near the end of T2 at
$125.5 \mathrm{ka}$, in spite of their different depth habitats and biogeographies (Figures 1 and 4). This major increase of the rare species was concomitant with the increase of the far more dominant transitional subpolar species $N$. pachyderma (d) and G. bulloides, although contrary to these latter two species all the rare species show peak abundances before $121 \mathrm{ka}$.

[17] Across OIS 5e a number of coinciding features are found in both the various abundance data and the two planktic isotope records. The main decline in rare species abundance after $121 \mathrm{ka}$ occurred contemporaneously with the significant isotopic offset observed in G. bulloides relative to N. pachyderma (d) at this time (Figure 4). All rare species more or less completely vanish from the area at $117 \mathrm{ka}$, after which $\delta^{18} \mathrm{O}$ values in $N$. pachyderma (d) started to rapidly increase. Although the main abundance peaks of the rare species fall into the time intervals marked by highest SSTs (between 125 and $121 \mathrm{ka}$ ), their early decline and overall variability, particularly that of the surface dweller G. ruber, mimics the $\delta^{18} \mathrm{O}$ trends recorded by $G$. bulloides.

[18] The disappearance of all rare species after $117 \mathrm{ka}$ was accompanied by a major increase in the abundance of G. bulloides and a coeval increase in $\delta^{18} \mathrm{O}$ values of $N$. pachyderma (d), altogether indicating that surface ocean properties underwent significant further changes during the OIS $5 \mathrm{e} / 5 \mathrm{~d}$ transition. Intriguingly, like with the previously described lack in isotopic offset between G. bulloides and $N$. pachyderma (d) during late OIS 1 , the comparably high abundances of $G$. bulloides (doubling from $20 \%$ to $40 \%$ ) after $115 \mathrm{ka}$ are also not recognizable in our youngest sediments. Because G. bulloides in the modern northern North Atlantic shows a clear association with subpolar water masses which are colder than at site 23414 (Figure 1), the relatively low values found during the late Holocene give further evidence that surface conditions here have not changed since $7 \mathrm{ka}$.

\section{Climatic Implications}

\subsection{Regional Developments and Reconstructions}

[19] OIS 5e is thought to more or less conform to the period of the last interglacial on land, traditionally named the Eemian in western Europe [Turon, 1984; Mangerud, 1989; Shackleton et al., 2003]. Climatologically, the most prominent feature of the last interglacial cycle, which had a strong effect on terrestrial and marine environments alike, was the worldwide melting of glacial ice caps at the end of the penultimate glaciation (OIS 6), followed by a notable regrowth of glacier ice during the OIS 5e-5d transition (Figure 5). Because of the rather warm surface ocean and atmospheric conditions, which developed across the North Atlantic between these times, deciduous woodlands with thermophilic trees became widespread in Europe (Figure 5). The duration of this warm phase, particularly in pollen records, has recently been a matter of controversy, but is thought to range from 13 to $23 \mathrm{kyr}$ [Turner, 2002].

[20] For various reasons, it seems problematic to strictly correlate marine with terrestrial records [cf. Müller and Kukla, 2004; Sánchez-Goñi et al., 1999]. Our data show that such problems become even more significant when the marine proxy indicators used, such as IRD and N. pachyderma (s), 


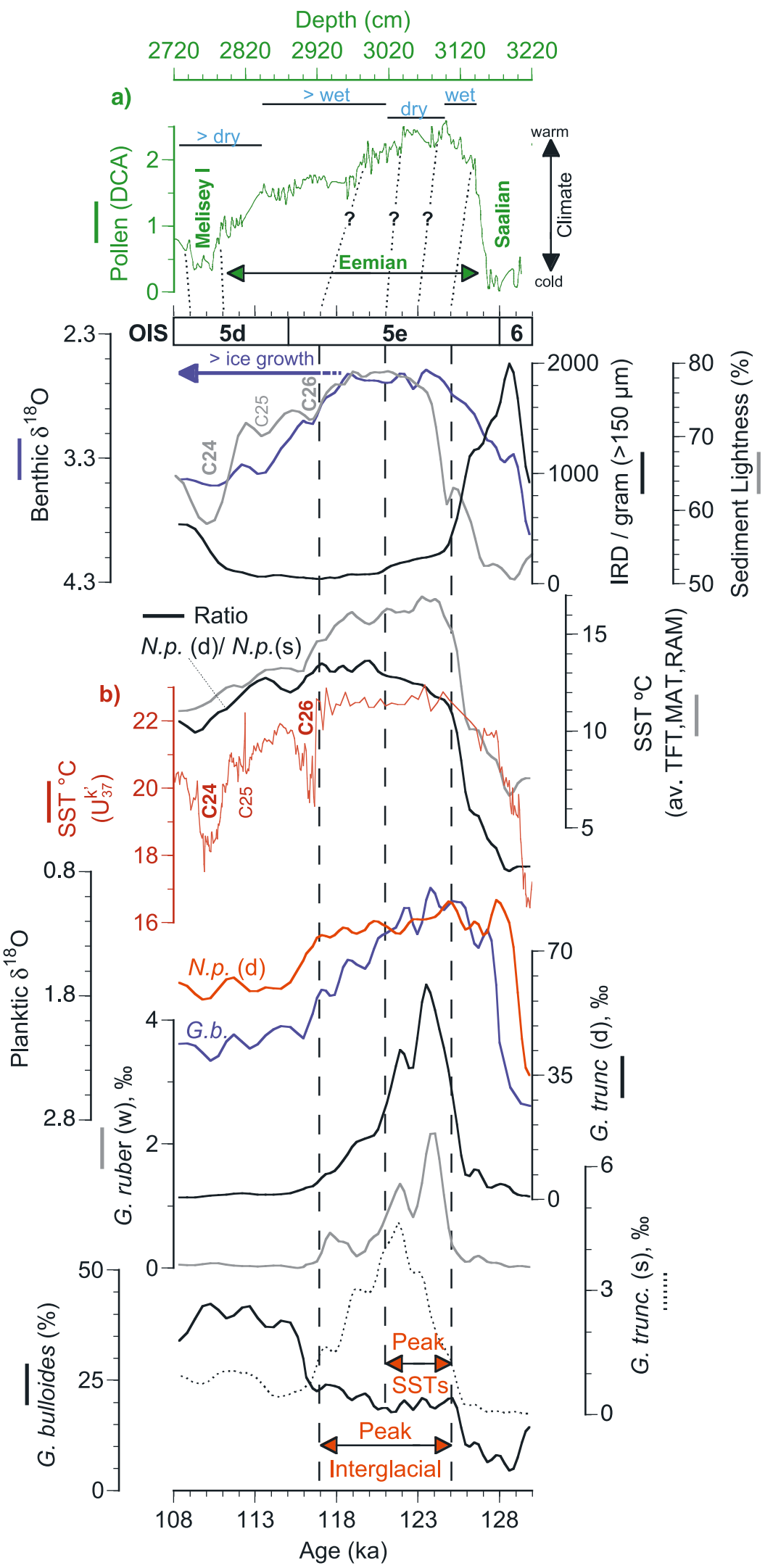

Figure 5 
are better suited to describe a cold environment. This is because any significant interglacial climatic change is amplified in the colder high latitudes, where major environmental processes are highly temperature sensitive and seasonally variable [Dickson, 1999]. It has been indicated on the basis of marine records that the climate deterioration heralding the last interglacial decline had a significant latitude-dependent, diachronous character [Bauch et al., 1996, 2000]. It is therefore only reasonable to also conclude that environmental conditions at middle-southern latitudes of western Europe changed with a considerable time lag relative to the high north.

[21] Compared to the later Eemian phase, with its timetransgressive climate character, the early Eemian development is considered rather uniform across northern Europe [Caspers et al., 2002; Tzedakis, 2003], with rapid spreading of woodland forests due to warm air temperatures and a wet, marinedriven climate [Rioual et al., 2001; Kühl and Litt, 2003]. Thus this phase should roughly correspond to the time with highest SSTs in our core (until $\sim 123 \mathrm{ka}$ ) when the influence of warm surface waters from southern latitudes was most intense, as confirmed by the peaks in G. truncatulinoides (d) and G. ruber (Figure 5). That rather wet conditions existed in Europe during times of rapidly disappearing Saalian ice sheets is further supported by terrestrial and shallow-shelf $\delta^{18} \mathrm{O}$ records. These all indicate intensified moisture conditions near the end of and just after T2 [Seidenkrantz and Knudsen, 1997; Rioual et al., 2001; Kühl and Litt, 2003].

[22] Once the hydrological situation became more balanced, after the main deglaciation processes of T2 had ceased, environmental conditions became progressively drier in northern central Europe after this early warm/wet phase [Kühl and Litt, 2003]. However, during this drier time in northern central Europe, southern France experienced wetter conditions again, probably because of an enhanced maritime climate (Figure 5). That is, there must have existed at this time a significant latitudinal gradient within Europe, which was associated with increased zonality in ocean-atmosphere circulation.

[23] The shift toward generally moister conditions in southern France during the mid-Eemian could be explained by the occurrence of lower SSTs observed in our core during times of decreasing solar irradiance. It seems reasonable to conclude that a general decrease in SSTs in the northeast Atlantic would enforce more abundant seasonal sea ice at high northern latitudes. It has been shown that a certain atmospheric configuration (i.e., the North Atlantic-Arctic Oscillation (NAO/AO) in its negative mode), leads to increased precip- itation over southern Europe and expansion of winter sea ice in the subarctic region [Dickson et al., 2000; Hurrell et al., 2001; Rigor et al., 2002]. The existence of such a dominantly zonal ocean-atmosphere circulation during mid-OIS 5e has been suggested previously on the basis of sediment records from the high-latitude Nordic Seas [Bauch et al., 1999]. The abundance fluctuations from 30 to $50 \%$ recognized in N. pachyderma (d) between 122 and $120 \mathrm{ka}$ (Figure 4) could reflect a certain instability of the NAD system during midOIS 5e that was caused by a displacement of the main water masses and their flow direction in the northeast Atlantic.

[24] Although precise correlations between terrestrial and marine events during mid-Eemian times require many assumptions [e.g., Sirocko et al., 2005], the steep increase in $\delta^{18} \mathrm{O}$ of G. bulloides at $121 \mathrm{ka}$, well within the phase of low global ice volume, is indicative of the first significant SST cooling in the North Atlantic, which probably also affected the environment on land [Cheddadi et al., 1998] (Figure 5). However, this early isotopic change in G. bulloides not only reflects a temperature cooling of the shallow water induced by decreasing insolation. The concomitant decreases in our warm provenance fossil proxies, each with quite different depth habitats, additionally imply that there was also a significant reduction in the influence or advection of water masses from the south to site M23414. Moreover, the fact that the $\delta^{18} \mathrm{O}$ signature in $N$. pachyderma (d) remained relatively stable for another 4 kyr may indicate that the temperature decrease after $121 \mathrm{ka}$ was primarily caused by a cooling/change of the springtime/ early summer water masses.

[25] With the steep increase in $\delta^{18} \mathrm{O}$ of $N$. pachyderma (d) after $117 \mathrm{ka}$, which ended the main phase of peak interglacial conditions, started a time when surface water across the North Atlantic experienced a major cooling. In our study area, as well as further to the west and south, this distinct decrease in SSTs (event C26) was associated with a significant isotopic change in the deep water which can be traced from the low latitudes as far north as the Nordic seas [Adkins et al., 1997; Chapman and Shackleton, 1999; Bauch and Erlenkeuser, 2003]. The concomitant increase in abundance of subpolar $G$. bulloides, notably well above its previous as well as Holocene levels, together with an increase of polar N. pachyderma (Figures 1 and 5) strongly suggests that this surface cooling was linked to an expansion of cold waters from the northwest, i.e., the Labrador Sea. Although C26 in the North Atlantic is generally not associated with increased IRD, there is evidence for enhanced detrital carbonate output via ice rafting from the Labrador Sea region [Bond et al.,

Figure 5. Smoothed proxy records in core M23414 depicting the major climate trends observed by us for the last interglacial period. To preclude any influence of the other occurring foraminiferal species, relative proportions of the two dominant subpolar and polar species $N$. pachyderma (d) and $N$. pachyderma (s) are shown as simple ratios (calculated from Figure 4c but drawn here without vertical scale). This ratio would indicate a much longer "warm phase" than reflected by the calculated SSTs, the $\delta^{18} \mathrm{O}$ in G. bulloides, and all rare species. The duration is similar to the $U_{37}^{k^{\prime}} \mathrm{SST}$ record from the subtropical western North Atlantic. The original age model of MD95-2036 [Lehman et al., 2002] has been slightly adjusted to our core M23414 by alignment of the 4\% level in the benthic $\delta^{18} \mathrm{O}$ records (at $130 \mathrm{ka}$ in M23414) and the prominent C24 event in both cores. (a) Marine records directly compared with terrestrial records from Ribains Maar in southern France, which reflect a summary of pollen and freshwater diatom results (DCA, detrended correspondence analysis) together with major trends in overall moisture conditions derived from $\delta^{18} \mathrm{O}$ in silicate [Rioual et al., 2001]. Despite some correlative uncertainty for the middle part of OIS 5e our comparison implies a close connection of the marine and terrestrial climate development across the midlatitude North Atlantic region. (b) Core MD95-2036. 
2001], at a time when sea level was already significantly lowered [Chapman and Shackleton, 1999].

[26] This widely recognizable C26 event, occurring during the early periods of ice growth, is clearly the first major climatic event to impact the North Atlantic. As such, it should also be found in terrestrial records of the neighboring landmasses. On the basis of the good visual correspondence between our marine records and pollen/lake data from southern France it is tempting to correlate the $\mathrm{C} 26$ event with a major environmental change identified in the Ribains record at $29.8 \mathrm{~m}$ (Figure 5).

[27] New $\delta^{18} \mathrm{O}$ data from North Greenland ice (N-GRIP), covering this interval of glacial inception after the OIS 5e plateau, show a clear cooling trend toward OIS $5 \mathrm{~d}$ [North Greenland Ice Core Project Members, 2004]. Along this OIS $5 \mathrm{e} / 5 \mathrm{~d}$ transition of the N-GRIP ice core there is a prominent isotopic change which has been correlated with the $\mathrm{C} 26$ cold event of the North Atlantic [North Greenland Ice Core Project Members, 2004]. However, a strong cooling over Greenland seems somewhat difficult to assess using the ice core data at face value because of the underlying progressive cooling trend which characterizes the OIS $5 \mathrm{e} / 5 \mathrm{~d}$ transition (Figure 3). What is clearly discernible in the N-GRIP data with the present age model, however, is a steep isotopic shift that represents an abrupt "warming" relatively late during the OIS $5 \mathrm{e} / 5 \mathrm{~d}$ transition. In the subtropical North Atlantic, however, the $\mathrm{C} 26$ event occurs comparatively early during the OIS 5e/5d transition (Figure 5) [Lehman et al., 2002].

[28] In the midlatitude North Atlantic, the cooling event $\mathrm{C} 25$ is the first during the late OIS $5 \mathrm{e} / 5 \mathrm{~d}$ transition to have clearly been identified with IRD (Figure 3) [Chapman and Shackleton, 1999]. Although this event is only weakly imprinted in most surface water proxies, the ready identification of $\mathrm{C} 25$ in benthic $\delta^{18} \mathrm{O}$ data underscores its climatic importance during this phase of glacial inception (Figure 5) [Chapman and Shackleton, 1999; Lehman et al., 2002]. Accordingly, the shift toward an increasingly drier and colder environment observed in southern France just before the stadial Melisey 1 fully developed would corroborate the marine data of progressing, glacial conditions over the North Atlantic sector which finally culminated in the major C24 event.

[29] That the published views on the duration of the Eemian/OIS 5e interval differ by as much as 10 kyr [Turner, 2002] may also be partly due to age uncertainties related to the climate transitions. According to our primitive age model based on benthic $\delta^{18} \mathrm{O}$, we argue that the interval of sea level highstand lasted 7-8 kyr and coincided with peak interglacial conditions. A similar estimate has also been derived in other studies from the North Atlantic [Adkins et al., 1997; Lehman et al., 2002], and gains additional support from absolute ages of corals in both the subtropical North Atlantic [e.g., Thompson and Goldstein, 2006], as well as from areas far away from northern hemisphere ice sheet fluctuations [e.g., Stirling et al., 1998].

\subsection{Interglacial Water Mass Changes: Causes and Effects}

[30] That the peak warm period is recognizable in core M23414 during the early phase of sea level highstand strongly suggests an overall causal link to northern summer insolation (Figure 4). The covarying minor changes in both the rare species abundances and in the $\delta^{18} \mathrm{O}$ record of $G$. bulloides seem to indicate the existence of surface ocean variability on smaller timescales. Such suborbitally scaled oceanic changes have also been reported by others for OIS $5 \mathrm{e}$ [Bond et al., 1999; Hillaire-Marcel et al., 2001; Oppo et al., 2001]. As for the Holocene, the underlying impetus for climate variability on these shorter timescales may be variations in solar output, amplified through other mechanisms such as the distribution of Arctic sea ice and changes in THC [Bond et al., 2001].

[31] Despite the overall analogy between Holocene and OIS 5e climate constraints, our data clearly show that surface ocean conditions evolved very differently during these two interglacials. The reason for that may be sought in the geographical configuration of late Saalian (OIS 6) ice in northern Europe, which was of much larger extent than at the last glacial maximum. Therefore its particular melting probably also affected the terrestrial and marine environments in distinctly different ways. Although marine records show a strong similarity between $\mathrm{T} 1$ and $\mathrm{T} 2$ in terms of some rapid climatic shifts [e.g., Sarnthein and Tiedemann, 1990; Lototskaya and Ganssen, 1999; Oppo et al., 2001], there is paleoceanographic evidence of north moving water masses in the northeast Atlantic sector and into the Nordic seas during the penultimate deglaciation that have no analogue in the last deglaciation [Bauch, 1996; Bauch et al., 2000]. One would expect that the particular water mass configuration during deglaciation had a continuing effect also on the postglacial surface ocean conditions at these high latitudes. For instance, a difference in seasonal surface ocean properties during mid-OIS 5e, with more winter sea ice coverage in subarctic areas where no sea ice exists today (i.e., the northeastern Nordic seas and Barents Sea), has been suggested before [cf. Bauch et al., 1999]. The general scenario as suggested by us for this time, with a dominantly zonal ocean-atmospheric circulation according to the negative NAO/AO mode, would lower the surface heat transfer to the higher Arctic. The same scenario may also account for a reduction in deep water formation as interpreted for relevant high-latitude sites [Hillaire-Marcel et al., 2001], likely as a result of surface freshening in summer upon melting of more abundant sea ice during winter.

[32] Using the Holocene postglacial water mass evolution for comparison, it seems not too surprising that the convergence of our planktic $\delta^{18} \mathrm{O}$ records at $7 \mathrm{ka}$ occurred at the time when deep water formation in the Labrador and Nordic seas was established [Hillaire-Marcel et al., 2001; Bauch et al., 2001], but after the final melting of Laurentide glaciers [Barber et al., 1999]. In this context of late Holocene versus late OIS 5e climatic evolution it is noteworthy that the regrowth of glaciers in Norway commenced already after the mid-Holocene temperature maximum [Nesje and Kvamme, 1991]. This regrowth of ice was contemporaneous with an east-west steepening of surface temperatures in the Nordic seas [Koç et al., 1993; Bauch et al., 2001], which forced all main oceanographic fronts into their present-day meridional alignment (Figure 1). If this late Holocene oceanic pattern in surface conditions of the Nordic seas was, following the $\mathrm{NAO} / \mathrm{AO}$ concept, the result of a general change toward a dominating positive mode then we have a viable mechanism 
that drives more moisture into the high latitudes to initiate glacier growth during times of decreasing summer insolation.

[33] It is widely suggested that a significant change in the meridional overturning circulation of the North Atlantic is the main driver behind less stable climate conditions [e.g., Marotzke, 2000]. However, in the context of what caused an abrupt cooling or warming in the interglacial past, the climatic perturbations observed during the OIS $5 \mathrm{e} / 5 \mathrm{~d}$ transition still remain enigmatic. Do they reflect a rapid cooling that recovered back to nearly where it was before, like it seems to do in the subtropical record for C26 (Figure 5), or do they represent unusual warming that punctuated a general cooling trend, as could be inferred from the new Greenland ice core data (Figure 3)?

\section{Conclusions}

[34] Although part of a broader glacial-interglacial pattern, on centennial-millennial timescales it is hard to reconcile the late Quaternary interglacial climate as a time with prolonged stability. This is because the climatic course of each wellpronounced warm interglacial must be considered to be constantly progressing. It should be expected that such a dynamic system undergoes typical transient changes but which nevertheless may cause a very distinct, individual environmental response. The eminent force behind interglacial changes and peculiarities has been identified here as the combined result of various processes. Of the processes involved, important ones are located in the northern latitudes, such as the particular configuration of glacial ice on land and its deglacial melting history. By influencing the North Atlantic heat engine and meridional overturning, these high-latitude processes determine how much and along what pathways atmospheric water vapor is transported across northern Eurasia at any given time. Because deciphering the particular hydrological conditions is the apparent key element in reconstructing past interglacial climate modes, and now also considered important in understanding major changes found in Greenland ice cores [North Greenland Ice Core Project Members, 2004; Masson-Delmotte et al., 2005], future work needs to focus on this topic. Specifically, a key goal should be to unravel the meridional gradients of surface ocean properties between the Arctic and low-latitude oceans and of the hydrological cycle on land. Our surface ocean study has shown that a better comprehension of such complex paleoenvironmental interrelations seems feasible when combining a variety of specific indicator proxies.

[35] Acknowledgments. The team from the Leibniz Laboratory at Kiel University (H. Erlenkeuser and N. Andersen) is thanked for their support in isotope analyses. J.-L. de Beaulieu, S. Lehman, A. Mix, and C. Turner added thoughtful comments to the draft manuscript. R. Schiebel provided useful hints on modern foraminiferal behavior. Thanks are expressed to B. Haley for improving the text. We very much appreciated the helpful review remarks made by W. Ruddiman and other anonymous referees. The project was funded through grants provided by Deutsche Forschungsgemeinschaft.

\section{References}

Adkins, J. F., E. A. Boyle, L. Keigwin, and E. Cortijo (1997), Variability of the North Atlantic thermohaline circulation during the last interglacial period, Nature, 390, 154-156. Antonov, J., S. Levitus, T. P. Boyer, M. Conkright, T. O'Brien, and C. Stephens (1998), World Ocean Atlas, vol. 1, Temperature of the Atlantic Ocean, NOAA Atlas NESDIS, vol. 27, 166 pp., NOAA, Silver Spring, Md.

Bandy, O. L. (1959), Geological significance of coiling ratios in the foraminifer Globigerina pachyderma (Ehrenberg), Geol. Soc. Am. Bull., 70, 1708 .

Barber, D. C., et al. (1999), Forcing of the cold event of 8,200 years ago by catastrophic drainage of Laurentide lakes, Nature, 400, 344-348.

Bauch, H. A. (1996), Monitoring termination II at high latitude: Anomalies in the planktic foraminiferal record, Mar. Geol., 131, 89-102.

Bauch, H. A., and H. Erlenkeuser (2003), Interpreting glacial-interglacial changes in ice volume and climate from subarctic deep water foraminiferal $\delta^{18} \mathrm{O}$, in Earth's Climate and Orbital Eccentricity: The Marine Isotope Stage 11 Question, Geophys. Monogr. Ser., vol. 137, edited by A. W. Droxler, R. Z. Poore, and L. H. Burckle, pp. 87-102, AGU, Washington, D. C.

Bauch, H. A., H. Erlenkeuser, P. M. Grootes, and J. Jouzel (1996), Implications of stratigraphic and paleoclimatic records of the last interglaciation from the Nordic Seas, Quat. Res., 46(3), 260-269.

Bauch, H. A., H. Erlenkeuser, K. Fahl, R. F. Spielhagen, M. S. Weinelt, H. Andruleit, and R. Henrich (1999), Evidence for a steeper Eemian than Holocene sea surface temperature gradient between Arctic and sub-Arctic regions, Palaeogeogr. Palaeoclimatol. Palaeoecol., 145(1-3), 95-117.
Bauch, H. A., H. Erlenkeuser, S. J. A. Jung, and J. Thiede (2000), Surface and deep water changes in the subpolar North Atlantic during termination II and the last interglaciation, Paleoceanography, 15(1), 76-84.

Bauch, H. A., H. Erlenkeuser, R. F Spielhagen, U. Struck, J. Matthiessen, J. Thiede, and J. Heinemeier (2001), A multiproxy reconstruction of the evolution of deep and surface waters in the subarctic Nordic seas over the last 30,000 years, Quat. Sci. Rev., 20(6), 659-678.

Berger, A. (1978), A simple algorithm to compute long-term variations of daily or monthly insolation, report, 39 pp., Univ. Cath. de Louvain, Louvain, Belgium.

Bond, G., et al. (1992), Evidence for massive discharges of icebergs into the North Atlantic ocean during the last glacial period, Nature, $360,245-249$

Bond, G. C., W. Showers, M. Elliot, M. Evans, R. Lotti, I. Hajdas, G. Bonani, and S. Johnson (1999), The North Atlantic's 1-2 kyr climate rhythm: Relation to Heinrich events, Dansgaard/Oeschger cycles and the Little Ice Age, in Mechanisms of Global Climate Change at Millennial Time Scales, Geophys. Monogr. Ser., vol. 112, edited by P. U. Clark, R. S. Webb, and L. D. Keigwin, pp. 35-58, AGU, Washington, D. C.

Bond, G., B. Kromer, J. Beer, R. Muscheler, M. N. Evans, W. Showers, S. Hoffmann, R. Lotti-Bond, I. Hajdas, and G. Bonan (2001), Persistent solar influence on North Atlantic climate during the Holocene, Science, 294, 2130-2136.

Caspers, G., J. Merkt, H. Müller, and H. Freund (2002), The Eemian interglaciation in northwestern Germany, Quat. Res., 58, $49-52$.
Chapman, M. R., and N. J. Shackleton (1999), Global ice-volume fluctuations, North Atlantic ice-rafting events, and deep-ocean circulation changes between 130 and $70 \mathrm{ka}$, Geology, 27, 795-798.

Cheddadi, R., K. Mamkowa, J. Guiot, J.-L. de Beaulieu, M. Reille, V. Andrieu, W. Granoszewski, and O. Peyron (1998), Was the climate of the Eemian stable? A quantitative climate reconstruction from seven European pollen records, Palaeogeogr. Palaeoclimatol. Palaeoecol., 143, 73-85.

CLIMAP Project Members (1976), The surface of the ice-age earth, Science, 191, 1131-1137.

Dickson, B. (1999), All change in the Arctic, Nature, 397, 389-391.

Dickson, R. R., T. J. Osborn, J. W. Hurrell, J. Meincke, J. Blindheim, B. Adlandsvik, T. Vinje, G. Alekseev, and W. Maslowski (2000), The Arctic Ocean response to the North Atlantic Oscillation, J. Clim., 13, 2671-2696.

Didié, C., and H. A. Bauch (2002), Implications of upper Quaternary stable isotope records of marine ostracodes and benthic foraminifera for paleoecological and paleoceanographical investigations, in The Ostracoda: Applications in Quaternary Research, Geophys. Monogr. Ser., vol. 131, edited by J. A. Holmes and A. R. Chivas, pp. 279-299, AGU, Washington, D. C.

Fronval, T., E. Jansen, J. Bloemendal, and S. Johnsen (1995), Oceanic evidence for coherent fluctuations in Fennoscandian and Laurentide ice sheets on millennium timescales, Nature, 374, 443-446.

Ganssen, G. M., and D. Kroon (2000), The isotopic signature of planktonic foraminifera from NE Atlantic surface sediments: Implications for the reconstruction of past oceanic 
conditions, J. Geol. Soc. London, 157(3), $693-699$.

Guiot, J., J. L. de Beaulieu, R. Cheddadi, F. David, P. Ponel, and M. Reille (1993), The climate in Western Europe during the last glacial/interglacial cycle derived from pollen and insect remains, Palaeogeogr. Palaeoclimatol. Palaeoecol., 103, 73-93.

Hatun, H., A. B. Sandø, H. Drange, and B. Hansen (2005), Influence of the Atlantic subpolar gyre on the thermohaline circulation, Science, 309, 1841-1844

Helmke, J. P., and H. A. Bauch (2001), Glacialinterglacial relationship between carbonate components and sediment reflectance in the North Atlantic, Geo Mar. Lett., 21(1), 16-22.

Helmke, J. P., M. Schulz, and H. A. Bauch (2002), Sediment-color record from the northeast Atlantic reveals patterns of millennialscale climate variability during the past 500,000 years, Quat. Res., 57, 49-57.

Hemleben, C., M. Spindler, and O. R. Anderson (1989), Modern Planktonic Foraminifera, 363 pp., Springer, New York.

Herman, Y. (1972), Globorotalia truncatulinoides: A paleo-oceanographic indicator, Nature, 238, 394-396.

Hillaire-Marcel, C., A. de Vernal, G. Bilodeau, and A. J. Weaver (2001), Absence of deepwater formation in the Labrador Sea during the last interglacial period, Nature, 410, $1073-1077$

Hurrell, J. W., Y. Kushnir, and M. Visbeck (2001), The North Atlantic Oscillation, Science, 291, 603-605.

Imbrie, J., and N. G. Kipp (1971), A new micropaleontological method for quantitative paleoclimatology: Application to a late Pleistocene Caribbean core, in The Late Cenozoic Glacial Ages, edited by K. K. Turekian, pp. 71-181, Yale Univ. Press, New Haven, Conn.

Kandiano, E. S., and H. A. Bauch (2003), Surface ocean temperatures in the northeast Atlantic during the last 500,000 years: Evidence from foraminiferal census data, Terra Nova, 4, 265-271.

Kandiano, E. S., H. A. Bauch, and A. Müller (2004), Sea surface temperature variability in the North Atlantic during the last two glacialinterglacial cycles: Comparison of faunal, oxygen isotopic and $\mathrm{Mg} / \mathrm{Ca}$-derived records, Palaeogeogr. Palaeoclimatol. Palaeoecol., 204, 145-164.

Kipp, N. G. (1976), New transfer function for estimating past sea-surface conditions from sea-bed distribution of planktonic foraminiferal assemblages in the North Atlantic, Mem. Geol. Soc. Am., 145, 3-41.

Koc,, N., E. Jansen, and H. Haflidason (1993), Paleoceanographic reconstructions of surface ocean conditions in the Greenland, Iceland and Norwegian seas through the last $14 \mathrm{ka}$ based on diatoms, Quat. Sci. Rev., 12, 115140

Kühl, N., and T. Litt (2003), Quantitative time series reconstruction of Eemian temperature at three European sites using pollen data, Vegetation Hist. Archaeobot., 12, 205-214.

Kukla, G., J. F. McManus, D.-D. Rousseau, and I. Chuine (1997), How long and how stable was the last interglacial?, Quat. Sci. Rev., 16, $605-612$

Lehman, S. J., J. P. Sachs, A. M. Crotwell, L. D. Keigwin, and E. A. Boyle (2002), Relation of subtropical Atlantic temperature, high-latitude ice rafting, deep water formation, and European climate 130,000-600,00 years ago, Quat. Sci. Rev., 21, 1917-1924.
Lohmann, G. P., and P. N. Schweitzer (1990), Globorotalia truncatulinoides' growth and chemistry as probes of the past thermocline: 1. Shell size, Paleoceanography, 5(1), 55-75.

Lototskaya, A., and G. M. Ganssen (1999), The structure of termination II (penultimate deglaciation and Eemian) in the North Atlantic, Quat. Sci. Rev., 18, 1641-1654.

Mangerud, J. (1989), Correlation of the Eemian and the Weichselian with deep sea oxygen isotope stratigraphy, Quat. Int., 3/4, 1-4.

Marotzke, J. (2000), Abrupt climate change and thermohaline circulation: Mechanisms and predictability, Proc. Natl. Acad. Sci. U. S. A., 97(4), 1347-1350

Martinson, D. G., N. G. Pisias, J. D. Hays, J. Imbrie, T. C. Moore, and N. J. Shackleton (1987), Age dating and the orbital theory of the Ice Ages: Development of a highresolution 0 to 300,000 years chronostratigraphy, Quat. Res., 27, 1-29.

Maslin, M., M. Sarnthein, and J. J. Knaack (1996), Subtropical eastern Atlantic climate during the Eemian, Narturwissenschaften, 83 , $122-126$.

Masson-Delmotte, V., J. Jouzel, A. Landais, M. Stievenard, S. J. Johnsen, J. W. C. White, M. Werner, A. Sveinbjornsdottir, and K. Fuhrer (2005), GRIP deuterium excess reveals rapid and orbital-scale changes in Greenland moisture origin, Science, 309, $118-121$.

McManus, J., G. Bond, W. Broecker, S. Johnsen, L. Labeyrie, and S. Higgins (1994), Highresolution climate records from the North Atlantic during the last interglacial, Nature, 371, 326-329.

McManus, J. F., D. W. Oppo, L. D. Keigwin, J. L. Cullen, and G. C. Bond (2002), Thermohaline circulation and prolonged interglacial warmth in the north Atlantic, Quat. Res., 58 $17-21$.

Müller, U. C., and G. J. Kukla (2004), North Atlantic Current and European environments during the declining stage of the last interglacial, Geology, 32, 1009-1012.

Nesje, A., and M. Kvamme (1991), Holocene glacier and climate variations in western Norway: Evidence for early Holocene glacier demise and multiple Neoglacial events, Geology, 19, 610-612

North Greenland Ice Core Project Members (2004), High-resolution record of Northern Hemisphere climate extending into the last interglacial period, Nature, 431, 147-151.

Oppo, D. W., M. Horowitz, and S. J. Lehman (1997), Marine core evidence for reduced deep water production during termination II followed by a relatively stable substage $5 \mathrm{e}$ (Eemian), Paleoceanography, 12(1), 51-63.

Oppo, D. W., L. D. Keigwin, J. F. McManus, and J. L. Cullen (2001), Persistent suborbital climate variability in marine isotope stage 5 and termination II, Paleoceanography, 16(3), 280-292.

Prell, W. L. (1985), The stability of low latitude sea surface temperatures: An evaluation of the CLIMAP reconstruction with emphasis on positive SST anomalies, Rep. TR025, 60 pp., U.S. Dep. of Energy, Washington D. C.

Rigor, I. G., J. M. Wallace, and R. L. Colony (2002), Response of sea ice to the Arctic Oscillation, J. Clim., 15, 2648-2663.

Rioual, P., V. Andrieu-Ponel, M. Rietti-Shati, R. W. Battarbee, J.-L. de Beaulieu, R. Cheddadi, M. Reille, H. Svobodova, and A. Shemesh (2001), High-resolution record of climate stability in France during the last interglacial period, Nature, 413, $293-$ 296.

Ruddiman, W. F., N. J. Shackleton, and A. McIntyre (1986), North Atlantic sea-surface temperatures for the last 1.1 million years, in North Atlantic Paleoceanography, edited by

C. P. Summerhayes and N. J. Shackleton, Geol. Soc. Spec. Publ., 21, 155-173.

Sánchez-Goñi, M. F., F. Eynaud, J. L. Turon, and N. J. Shackleton (1999), High resolution palynological record off the Iberian margin: Direct land-sea correlation for the last interglacial complex, Earth Planet. Sci. Lett., 171, 123 137.

Sarnthein, M., and R. Tiedemann (1990) Younger Dryas-style cooling events at glacia terminations I-VI at ODP-Site 658: Associated benthic $\delta^{13} \mathrm{C}$ anomalies constrain meltwater hypothesis, Paleoceanography, 5(6), 1041-1055.

Schiebel, R., and C. Hemleben (2000), Interannual variability of planktic foraminiferal populations and test flux in the eastern North Atlantic Ocean (JGOFS), Deep Sea Res., Part II, 47, 1809-1852.

Schiebel, R., J. Waniek, M. Bork, and C. Hemleben (2001), Planktic foraminiferal production stimulated by chlorophyll redistribution and entrainment of nutrients, Deep Sea Res., Part I, 48, 721-740.

Seidenkrantz, M.-S., and K. L. Knudsen (1997), Eemian climatic and hydrographical instability on a marine shelf in northern Denmark, Quat Res., 47, 218-234.

Shackleton, N. J., M. F. Sanchez-Goni, D. Pailler, and Y. Y. Lancelot (2003), Marine isotope substage $5 \mathrm{e}$ and the Eemian interglacial, Global Planet. Change, 36, 151-155.

Sirocko, F., K. Seelos, K. Schaber, B. Rein, F. Dreher, M. Diehl, R. Lehne, K. Jäger, M. Krbetschek, and D. Degering (2005), A late Eemian aridity pulse in central Europe during the last glacial inception, Nature, 436, 833 836.

Stirling, C. H., T. M. Esat, L. Lambeck, and M. T. McCulloch (1998), Timing and duration of the last interglacial: Evidence for a restricted interval of widespread coral reef growth, Earth Planet. Sci. Lett., 160, 745-762.

Thiede, J. (1971), Variations in coiling ratios of Holocene planktonic foraminifera, Deep Sea Res. Oceanogr. Abstr., 18, 823-831.

Thompson, W. G., and S. L. Goldstein (2006), A radiometric calibration of the SPECMAP timescale, Quat. Sci. Rev., doi:10.1016/ j.quascirev.2006.02.007, in press.

Turner, C. (2002), Problems of the duration of the Eemian interglacial in Europe north of the Alps, Quat. Res., 58, 45-48.

Turon, J.-L. (1984), Direct land/sea correlations in the last interglacial complex, Nature, 309, 673-676.

Tzedakis, C. (2003), Timing and duration of last interglacial conditions in Europe: A chronicle of a changing chronology, Ouat. Sci. Rev., 22(8-9), 763-768.

Waelbroeck, C., L. Labeyrie, J.-C. Duplessy, J. Guiot, M. Labracherie, H. Leclaire, and J. Duprat (1998), Improving past sea surface temperature estimates based on planktonic fossil faunas, Paleoceanography, 13(3), 272-283.

H. A. Bauch and E. S. Kandiano, IFMGEOMAR, Wischhofstrasse 1-3, D-24148 Kiel, Germany. (hbauch@ifm-geomar.de) 